\title{
ISLAM DAN KRISIS LINGKUNGAN HIDUP (REKONSTRUKSI PARADIGMA MENUJU ISLAM RAMAH LINGKUNGAN)
}

\author{
Fikria Najitama dan Chusnul Chotimah \\ Institut Agama Islam Nahdlatul Ulama (IAINU) Kebumen \\ e-mail: fikrianajitama@gmail.com
}

\begin{abstract}
Abstrak
Artikel ini dipicu munculnya banyak kritik dari para akademisi mengenai posisi agama monoteisme dalam konteks kerusakan lingkungan. Arnold Toynbee misalnya, menganggap bahwa krisis lingkungan hidup disebabkan oleh agama-agama monoteisme yang menghilangkan rasa hormat terhadap alam ilahi sehingga tidak ada lagi yang menahan ketamakan manusia. Tulisan ini merupakan ikhitiar untuk memberikan gambaran bahwa persoalan krisis lingkungan hidup merupakan persoalan global yang menuntut semua kalangan untuk meresponnya. Dalam konteks ini, Islam juga harus memberikan solusi dengan melakukan pembacaan ulang pada bangunan keilmuan yang diharap memberi dampak pada munculnya shitf paradigm terkait konsep teologi, etika, dan fiqh yang selama ini masih dikuasai dengan cara berpikir klasik yang kurang memberi respon dan landasan dalam konservasi lingkungan.
\end{abstract}

Kata Kunci: Islam, Krisis Lingkungan, Paradigma

\section{A. Pendahuluan}

Dalam beberapa dekade belakangan ini, persoalan yang dihadapi oleh manusia semakin beragam. Perkembangan sejarah kehidupan manusia ternyata juga membawa manusia pada kompleksitas masalah. Fukuyama misalnya, mensinyalir bahwa masyarakat sekarang ini mengalami great 
disruption yang menyebabkan munculnya gangguan-gangguan serius terhadap nilai-nilai sosial. Kenyataan ini dapat dilihat dari statistik kriminalitas yang semakin tinggi, anak-anak tanpa orang tua, terbatasnya akses serta kesempatan untuk pendidikan, saling curiga, dan sebagainya. ${ }^{1}$ Selain itu, perkembangan bio-teknologi juga menimbulkan berbagai problem krusial bagi manusia. Munculnya bom nuklir, kerusakan lingkungan akibat teknologi, dan berbagai masalah akibat kemajuan teknologi merupakan realitas yang dapat disaksikan saat ini.

Dinamika kontemporer menimbulkan banyak implikasi dan tantangan bagi agama. Agama sebagai landasan dan pandangan hidup dituntut untuk dapat merespon realitas. Banyak isu-isu kontemporer yang membuat agama kelimpungan untuk meresponnya. Persoalan krisis lingkungan hidup merupakan salah satu isu kontemporer yang sangat menggelisahkan. Persoalan krisis lingkungan hidup bukan hanya problem masyarakat tertentu, namun sudah menjadi problem global. Dalam kondisi ini, beberapa pemikir menilai bahwa salah satu penyebab munculnya krisis lingkungan disebabkan oleh agama. Seorang ahli sejarah, Lynn White menyatakan bahwa apa yang dilakukan oleh manusia terhadap ekologinya tergantung pada apa yang mereka pikirkan tentang mereka sendiri dalam hubungannya dengan apa yang ada di sekitar mereka. Lebih tegas lagi dikatakan bahwa ekologi manusia sangat dipengaruhi oleh keyakinan tentang alam kita dan takdirnya, yaitu oleh agama. ${ }^{2}$ Arnold Toynbee, menyatakan bahwa krisis lingkungan hidup disebabkan oleh agamaagama monoteisme yang menghilangkan rasa hormat terhadap alam ilahi, sehingga tidak ada lagi yang menahan ketamakan manusia. ${ }^{3}$ Kenyataan ini memicu para akademisi seperti Fazlun Khalid ${ }^{4}$, Martin Harun ${ }^{5}$ dan Frymer-

1 Francis Fukuyama, The Great Disruption: Human Nature and the Reconstruction of Social Order, (New York: The Free Press, 1999), hlm. 3-5.

2 White, Jr. L. Science, 'The Historical Roots of Our Ecologic Crisis”, Science vol. 155, 1967, hlm. 1203.

3 Martin Harun, "Taklukkan Bumi dan Berkuasalah..." dalam Mujiono Abdillah, Agama Ramah Lingkungan Perspektif Al-Qur'an, (Jakarta: Paramadina, 2001), hlm. xv.

4 Fazlun M. Khalid, "The Disconnected People" dalam Richard C. Foltz, Worldviews, Religion, and the Environment: A Global Anthology, (Australia: Thomson Wadsworth, 2003), hlm. 385-391.

5 Martin Harun, "Taklukkanlah Bumi dan Berkuasalah..." dalam Mujiono Abdillah, Agama Ramah Lingkungan Perspektif Al-Qur'an, (Jakarta: Paramadina, 2001), hlm. xi-xliv. 
$\mathrm{Kensky}^{6}$ untuk merespon kritik tersebut dengan memberikan pemahaman yang proposional mengenai konsep agama-agama.

Dalam konteks kontemporer, para pemikir Indonesia juga berusaha merespon kritik dengan memberikan gambaran konsep agama mengenai lingkungan hidup. Sebagian akademisi masih berusaha melakukan apologi dengan menandaskan bahwa agama sebenarnya sudah merespon persoalan lingkungan hidup. ${ }^{7}$ Namun sebagian yang lain, berusaha untuk merekonstruksi pemahaman agama yang dirasa memang kurang begitu kuat merespon persoalan lingkungan hidup. ${ }^{8}$

Artikel ini merupakan ikhitiar untuk memberikan gambaran bahwa persoalan krisis lingkungan hidup merupakan persoalan global yang menuntut semua kalangan untuk meresponnya. Dalam konteks ini, Islam juga harus memberikan solusi dan respon dengan melakukan pembacaan ulang terkait dengan konsep teologi, etika, dan fiqh yang selama ini masih dikuasai dengan cara berpikir klasik yang kurang memberi respon dan landasan dalam konservasi lingkungan. Demikian perlu sebuah rekonstrusi dan pembacaan ulang menuju Islam yang ramah lingkungan.

\section{B. Agama dan Problem Ekologi}

Krisis lingkungan hidup merupakan salah satu isu signifikan yang menjadi pembahasan dalam beberapa dekade belakangan ini. Isu-isu seperti pemanasan global, krisis energi, kerusakan hutan dan sebagainya, memaksa manusia untuk berusaha mencari jalan keluar untuk menanggulanginya. ${ }^{9}$ Masalah tersebut bukan hanya monopoli satu kawasan saja, namun sudah menjadi serangkaian masalah global yang membahayakan kehidupan hidup manusia.

6 Tikva Frimer-Kensky, "Ecology in a Biblical Perspective" dalam Richard C. Foltz, Worldviews, Religion, and the Environment: A Global Anthology, (Australia: Thomson Wadsworth, 2003), hlm. 290-296.

7 Untuk akademisi model apologi adalah Thalhah dan Ahmad Mufid dengan bukunya yang berjudul Fiqh Ekologi. Lihat, Thalhah dan Ahmad Mufid, Figh Lingkungan: Menjaga Bumi Memahami Makna Kitab Suci, (Yogyakarta: Total Media, 2008).

8 Abdullah, Mudhofir, Al-Qur'an dan Konservasi Lingkungan, (Jakarta, Dian Rakyat, 2010).

9 Lihat, Mujiono Abdillah, Agama Ramah Lingkungan Perspektif Al-Qur'an, (Jakarta: Paramadina, 2001), hlm. 21-97. 
Terkait dengan realitas tersebut, banyak ilmuan yang berusaha mengkaji dan menelaah terkait dengan akar persoalan munculnya krisis lingkungan hidup. ${ }^{10}$

Sonny Keraf melihat bahwa krisis lingkungan lebih terkait dengan kesalahan cara pandang yang menempatkan manusia sebagai pusat dari alam semesta (antroposentris). ${ }^{11}$ Cara pandang ini kemudian menimbulkan sifat eksploitatif tanpa memperdulikan lingkungan. Konsep paradigma antroposentrisme ini melahirkan tiga kesalahan cara pandang, yakni: pertama, manusia dipahami hanya sebagai makhluk sosial yang eksisensi dan identitas dirinya ditentukan oleh komunitas sosialnya. Dengan demikian, hal ini menafikan realitas bahwa manusia juga merupakan makhluk ekologis. Kedua, etika hanya berlaku bagi komunitas sosial manusia. Dengan pandangan ini, alam dan seluruh isinya hanya diperlakukan sebagai alat manusia, dan tidak ada rumusan etika dengan selain manusia. Ketiga, cara pandang ilmu pengetahuan yang berciri mekanistis-reduksionis. Cara pandang ini sangat mendukung ilmu pengetahuan modern yang bebas nilai. Dengan demikian, penilaian baik buruk menjadi tidak relevan. Hal ini kemudian melahirkan sikap manipulatif dan eksploitatif terhadap alam yang kemudian menimbulkan krisis lingkungan. ${ }^{12}$ Pendapat Keraf yang menggapap bahwa manusia lebih menekankan pada aspek paradigma antroposentris cukup beralasan. Kasus kerusakan hutan (illegal logging) misalnya, merupakan bentuk eksploitasi manusia berlebihan yang tidak memikirkan dampak ekologi. ${ }^{13}$

Menurut Abdullah, salah satu akar krisis lingkungan adalah krisis spiritual. Krisis ini bersifat subyektif dan terkait dengan krisis pandangan hidup, etika perilaku, teologi agama, atau kearifan-kearifan tradisi budaya yang dianut oleh manusia. ${ }^{14}$ Dalam literatur Islam, krisis spiritual merupakan krisis keimanan. Dalam keimanan, terdapat dua sifat yang muncul terkait dengan nikmat Tuhan, yakni kufur dan syukur. Syukur merupakan sifat yang berterima kasih

10 White misalnya yang berargumen bahwa agama merupakan akar dari persoalan krisis lingkungan. Lihat, White, Jr. L. Science, 'The Historical Roots of Our Ecologic Crisis”, dalam Science, vol. 155, 1967.

11 A. Sonny Keraf, Etika Lingkungan Hidup, (Jakarta: Kompas, 2010), hlm. 3

12 Ibid., hlm. 3-8.

13 Kajian yang cukup baik dalam sisi data mengenai isu ini, lihat. Thalhah dan Ahmad Mufid, Fiqh Lingkungan: Menjaga Bumi Memahami Makna Kitab Suci, (Yogyakarta: Total Media, 2008), hlm. 83-95.

14 Mudhofir Abdullah, Al-Qur'an dan Konservasi Lingkungan, (Jakarta, Dian Rakyat, 2010), hlm. 94. 
atas nikmat Tuhan. Sedangkan kufur merupakan sifat yang destruktif dan tidak berterima kasih atas nikmat Tuhan. Sikap kufur nikmat Tuhan inilah yang kemudian melahirkan krisis spiritual. ${ }^{15}$ Pendapat ini dilandaskan pada pemikiran Seyyed Hossein Nasr, bahwa krisis spiritual merupakan krisis terbesar yang mengakibatkan krisis material, krisis lingkungan, dan krisis semua ciptaan. ${ }^{16}$ Pendapat tersebut secara tidak langsung mengungkapkan bahwa krisis lingkungan dipengaruhi oleh krisis kesadaran spiritual manusia kontemporer.

Lynn White mengungkapkan dengan lebih tajam lagi, bahwa krisis lingkungan hidup kontemporer disebabkan oleh agama. Dia menyatakan bahwa apa yang dilakukan oleh manusia terhadap ekologinya tergantung pada apa yang mereka pikirkan tentang mereka sendiri dalam hubungannya dengan apa yang ada di sekitar mereka. Lebih tegas lagi dikatakan bahwa ekologi manusia sangat dipengaruhi oleh keyakinan tentang alam kita dan takdirnya, yaitu oleh agama. ${ }^{17}$ Pendapat White senada dengan Arnold Toynbee yang menyatakan bahwa krisis lingkungan hidup disebabkan oleh agama-agama monoteisme yang menghilangkan rasa hormat terhadap alam ilahi, sehingga tidak ada lagi yang menahan ketamakan manusia. ${ }^{18}$

Kritik tajam terkait dengan posisi agama dalam persoalan krisis lingkungan kemudian menimbulkan respon dari para akademisi agama. Banyak pendapat yang berusaha mendudukan persoalan bahwa bukan agama yang menjadi akar krisis, namun kesadaran beragama manusia yang lemah. ${ }^{19}$ Namun juga terdapat pemahaman yang memandang bahwa kritik tersebut merupakan kesalahan penafsiran atas kitab suci yang dianggap sangat simplistik. ${ }^{20}$

Dalam konteks Islam, persoalan lingkungan merupakan isu baru yang mendapatkan respon serius oleh banyak akademisi seperti Fazlun Khalid,

15 Ayat yang dijadikan landasan adalah QS. Ibrahim (14): 7.

16 Mudhofir Abdullah, Al-Qur'an..., hlm. 95-96.

17 White, Jr. L. Science, 'The Historical Roots..., hlm. 1203.

18 Martin Harun, "Taklukkan Bumi..., hlm. xv.

19 Sebagaimana pendapat Seyyed Hossein Nasr yang mengungkapkan bahwa krisis lingkungan dipengaruhi oleh krisis kesadaran spiritual manusia kontemporer. Lihat, Mudhofir Abdullah, $\mathrm{Al}$ Qur'an...,hlm. 95-96.

20 Lihat pemahaman Martin Harun yang melihat White tidak memahami secara benar dalam melakukan intepretasi Alkitab. Martin Harun, "Taklukkan Bumi dan Berkuasalah..." dalam Mujiono Abdillah, Agama Ramah Lingkungan Perspektif Al-Qur'an, (Jakarta: Paramadina, 2001), hlm. xi-xlii. 
Mujiono Abdullah, dan sebagainya. Konstruksi paradigma Islam selama ini belum secara kuat memotret persoalan lingkungan hidup. Dalam hal teologi misalnya, paradigma berpikir yang muncul masih lebih bercorak 'klasik'. Kajian teologi masih berorientasi pada perdebatan yang bersifat teosentris saja, dan sering menafikan orientasi kemanusiaan. Hal inilah yang kemudian melahirkan reorientasi menuju teologi baru seperti yang dilakukan oleh Hasan Hanaf $^{21}$. Kuatnya paradigma teosentris tersebut ternyata tidak berbanding lurus dengan pengamalan. Meskipun diskursus teologi cenderung teosentris, namun perilakunya cenderung antroposentris. Realitas antroposentrisme dalam tindakan menimbulkan problem tersendiri. Dampak yang muncul adalah bahwa persoalan lingkungan bukan merupakan bagian dari interaksi teologis manusia. Corak ini kemudian menimbulkan implikasi etika yang berujung pada menempatkan manusia sebagai pusat orientasi. Bahkan dalam ranah fiqh yang merupakan landasan perilaku dan perbuatan manusia, persoalan lingkungan kurang mendapatkan porsi. ${ }^{22}$ Selama ini, fiqh hanya bergulat dalam dimensi nalar klasik saja yang melahirkan konsep-konsep dasar seperti ibadah dan muammalah. ${ }^{23}$

Dari kenyataan inilah, penting kira mencari konstruksi paradigma Islam yang dapat menjadi landasan dalam berinteraksi dengan lingkungan. Problem paradigma klasik yang berujung pada sifat antroposentrime umat harus digeser ke arah paradigma Islam yang ramah lingkungan. Dengan demikian, rekontruksi teologi, etika, dan fiqh klasik menjadi sangat penting bagi umat Islam dalam menghadapi realitas krisis lingkungan hidup kontemporer.

\section{Paradigma Teologi Islam}

Teologi lingkungan merupakan konsep baru dalam diskursus kajian teologi. Kajian ini merupakan respon penyikapan secara teologis terkait dengan persoalan lingkungan. Dalam diskursus akademisi teologi muslim

21 Hasan Hanafi, Dari Akidah ke Revolusi: Sikap Kita Terhadap Tradisi Lama, terj. Asep Usman dkk (Jakarta: Paramadina, 2003).

22 Dalam fiqh klasik biasanya yang dianggap bagian dari diskursus lingkungan adalah hima' dan ihya al-mawat.

23 Lihat kitab-kitab fiqh klasik seperti karya Abi Yahya Zakariyya, Fath al-Wahhab, (Semarang: Toha Putra, tt.) dan Taqiyuddin Abu Bakar, Kifayah al-Akhyar, (Semarang: Toha Putra, tt.) 
klasik, kajian mengenai teologi lingkungan belum mendapat porsi. Akademisi muslim klasik masih berkutat dalam diskursus teologi yang memfokuskan pada kajian mengenai 'Tuhan'. Kajian pada fase akademisi teologi pertengahan sudah mulai berkembang, namun belum menyentuh persoalan lingkungan. Hal ini dikarenakan persolan lingkungan pada fase itu belumlah menimbulkan persoalan. Namun dimasa kontemporer, persoalan lingkungan sudah begitu memprihatinkan, sehingga membutuhkan respon yang serius dari berbagai kalangan, termasuk didalamnya adalah para akademisi seperti Khalid dan Mujiono.

Dalam diskursus teologi lingkungan, Islam bukanlah satu-satu agama yang mencoba merumuskan konsep teologinya terkait dengan lingkungan. Kajian teologi lingkungan juga dikembangkan oleh para agama-agama lainnya. ${ }^{24}$ Dengan kata lain, persoalan lingkungan hidup merupakan problem dan memunculkan keprihatinan bagi semua agama. Berlandaskan hal tersebut, para akademisi berusaha menelaah khazanah literaturnya untuk merumuskan konsep teologinya untuk merespon krisis-krisis lingkungan yang semakin parah seperti krisis energi, pemanasan global, dan sebagainya. ${ }^{25}$

Namun selain adanya realitas lingkungan kontemporer yang semakin rusak, munculnya kajian teologi lingkungan juga didorong oleh adanya kritikkritik yang menjustifikasi bahwa agama-agama-khususnya monoteisme- harus bertanggungjawab atas kerusakan lingkungan. Arnold Toynbee misalnya, menyatakan bahwa krisis lingkungan hidup disebabkan oleh agama-agama monoteisme yang menghilangkan rasa hormat terhadap alam ilahi, sehingga tidak ada lagi yang menahan ketamakan manusia. ${ }^{26}$ Kenyataan ini tentunya memicu para teolog untuk merespon kritik tersebut dengan memberikan pemahaman yang proposional mengenai konsep teologi agama-agama.

Dalam masyarakat, teologi yang berkembang dan dianut lebih condong kepada antroposentrisme. ${ }^{27}$ Paradigma ini ditandai dengan muncul dan

24 Lihat, Richard C. Foltz (ed.), Wordview, Religion, and the Environment: A Global Anthology, (Thomson Wadsworth, 2003).

25 Lihat, Mujiono Abdillah, Agama Ramah..., hlm. 21-97.

26 Martin Harun, "Taklukkan Bumi..., hlm. xv.

27 Mujiyono Abdillah, "Rekonstruksi Teologi Lingkungan dalam Pembangunan Masyarakat Madani”, dalam Innovatio, (vol. 5, No. 10 Edisi Juli-Desember 2006), hlm. 289. 
melonjaknya kesadaran bahwa manusia merupakan makhluk istimewa dan berkuasa atas alam. Dengan kata lain, paradigma ini mengacu pada keyakinan bahwa manusia merupakan makhluk elite, exlusive, dan segenap oganisme di luar manusia diciptakan dan disediakan untuk kepentingan dan kebutuhan manusia. Dari hal tersebut dapat disimpulkan bahwa paradigma antroposentrisme merupakan ekologi yang mana memposisikan lingkungan sebagai nilai untung bagi manusia. Hal inilah yang kemudian memberi jalan kepada manusia bersifat eksploitatif terhadap lingkungan. Kasuskasus kerusakan hutan akibat illegal logging bisa menjadi bukti. Lingkungan dieksploitasi demi kepentingan manusia tanpa mempertimbangkan kelestariannya.

Perkembangan ilmu dan teknologi yang memiliki paradigma antroposentrisme juga semakin membuat manusia semakin mengukuhkan dominasinya atas alam. Hal ini dikarena ilmu dan teknologi yang diciptakan merupakan alat untuk mengekploitasi lingkungan dan sumberdaya alam demi memenuhi ambisi kebutuhan manusia. Lingkungan direkayasa sedemikian rupa tanpa memperhatikan aspek negatif yang muncul. Implikasinya tentu saja membuat lingkungan menjadi tidak seimbangan serta merusak ekosistem yang ada. Sebagai misal adalah pemakaian bahan kimia yang satu segi meningkatkan produktifitas, namun dalam segi yang lain menimbulkan pencemaran dan merusak ekosistem. Namun bagi masyarakat berparadigma antroposentisme, hal tersebut tetap dilakukan, karena titik tolak nilai yang dikejar adalah keuntungan bagi manusia.

Teologi lingkungan Islam secara konseptual berbeda dengan teologi antroposentrisme radikal yang menempatkan manusia dalam posisi paling berkuasa atas lingkungan. ${ }^{28}$ Dalam hal ini, teologi lingkungan Islam menempatkan manusia dalam posisi yang proposional dan seimbang dengan alam. Konstruksi ini otomatis menempatkan manusia sebagai bagian integral dari lingkungan.

Landasan teologi lingkungan Islam didasarkan pada rumusan al-Qur'an antara lain adalah Q.S. Ar-Rahman: 10 dan Q.S. Al-Baqarah: 29. Kedua ayat tersebut menjelaskan bahwa lingkungan diciptakan dan untuk didayagunakan

28 Ibid., hlm. 291. 
oleh manusia. Dari ayat tersebut dapat ditarik makna secara teologis bahwa Allah telah menciptakan sumber daya alam dan lingkungan untuk didayagunakan oleh manusia. Keyword dari ayat tersebut adalah pada kata lam. Secara semantik, lam tersebut memiliki arti hak memanfaatkan (lam lit-tanfi') bukan lam yang bermakna memiliki (lam lit-tamlik). ${ }^{29}$ Dengan demikian, pada dasarnya manusia diberi hak dan kewenangan untuk memanfaatkan sumberdaya alam dan lingkungan. Namun hal tersebut diberi aturan dengan batas-batas keseimbangan dan kewajaran, karena di ayat-ayat yang lain manusia juga diingatkan supaya tidak berbuat kerusakan terhadap lingkungan. Dari landasan tersebut dapat disimpulkan bahwa teologi Islam mendasarkan pada paradigma keseimbangan, bukan pada paradigma antroposentrisme radikal. Hal ini juga didasarkan pada keyakinan dalam teologi Islam bahwa pemilik hakiki alam semesta adalah Allah.

\section{Paradigma Etika Islam}

Selain memunculkan kajian teologi lingkungan, krisis lingkungan juga kemudian mendorong tumbuhnya diskursus etika lingkungan. ${ }^{30} \mathrm{Hal}$ ini dikarenakan isu dan krisis lingkungan telah menyeret kajian mengenai etika dalam posisi yang rumit dan kompleks. Pokok persoalan yang didiskusikan adalah mengenai landasan etika terkait aktifitas manusia dalam hubungannya dengan lingkungan.

Dalam diskursus etika lingkungan, memunculkan dua paradigma etika, yaitu shallow-ecology (ekologi dangkal) dan deep-ecology (ekologi dalam). ${ }^{31}$ Kedua paradigma inilah yang kemudian dijadikan landasan untuk melihat aktifitas dan perilaku manusia terkait dengan lingkungan. Shallow-ecology merupakan paradigma yang menekankan pada aspek pemenuhan kebutuhan manusia. $^{32}$ Konsep ini mendudukkan lingkungan sebagai sarana yang dimanfaatkan demi kebutuhan manusia. Dengan demikian, shallow-ecology bersifat antroposentris dalam artian mendudukkan manusia sebagai makhluk

29 Ibid., hlm. 292.

30 Mengenai teori-teori etika, lihat, A. Sonny Keraf, Etika Lingkungan..., hlm. 45-165.

31 Lihat, Mudhofir Abdullah, Al-Qur'an dan..., hlm. 193.

32 Ibid, hlm. 193. 
superior yang punya wewenang bebas dalam melakukan eksploitasi dan pemanfaatan lingkungan demi kebutuhannya.

Karakteristik shallow-ecology tersebut tentunya memiliki dampak buruk bagi alam. Kecendrungan shallow-ecology yang muncul kemudian direspon dengan adanya paradigma deep-ecology yang mencoba memposisikan alam sebagai bagian tidak terpisahkan dari eksistensi manusia. Deep-ecology merupakan etika yang memandang bahwa manusia merupakan bagian integral dari lingkungannya. Konsep ini menempatkan sistem etika baru dan memiliki implikasi positif dalam kelestarian alam. Deep-ecology merupakan konsep yang visioner dan memiliki bobot kuat dalam implementasi. Menurut Arne Naess ${ }^{33}$, prinsip-prinsip deep-ecology adalah:

1. Kesejahteraan dan perkembangan manusia dan non-manusia di muka bumi memiliki nilai di dalam dirinya sendiri (seperti nilai instrinsik atau nilai inheren). Nilai tersebut tidak bergantung dari nilai guna dunia non-manusia untuk tujuan-tujuan manusia.

2. Kekayaan dan keragaman bentuk-bentuk kehidupan berkontribusipada kesadaran nilai-nilai mereka sendiri, dan juga nilai-nilai inherennya.

3. Manusia tidak memiliki hak untuk mengurangi hak dan keragaman lingkungan kecuali untuk memenuhi kebutuhan pokok saja.

4. Perkembangan hidup dan budaya manusia sepadan dengan pengurangan substansial populasi manusia. Perkembangan kehidupan non-manusia memerlukan pengurangan semacam ini.

5. Intervensi manusia modern atas dunia non-manusia terlalu berlebihan, dan kondisi ini semakin memburuk. Karena itu, kebijakan-kebijakan harus diubah. Kebijakan tersebut mempengaruhi struktur dasar ekonomi, teknologi, dan juga ideologi. Keadaan yang dihasilkan akan berbeda dengan keadaan sebelumnya.

6. Perubahan ideologi yang utama adalah penghormatan pada kualitas hidup (yakni dalam kondisi-kondisi nilai inheren) bukannya mempertahankan standar hidup yang semakin tinggi. Selanjutnya akan memunculkan kesadaran mendalam terhadap perbedaan antara yang besar dan besar sekali (the difference between big and great).

33 Mengenai pemikiran Arne Naess, lihat, A. Sonny Keraf, Etika Lingkungan..., hlm. 92-109. 
7. Mereka yang mendukung poin-poin tersebut memiliki kewajiban menerapkan peruahan-perubahan mendesak tersebut, baik secara langsung atau tidak langsung. ${ }^{34}$

Konsep deep-ecology selanjutnya juga melahirkan beberapa bentuk dalam aplikasinya, yaitu: Pertama, deep-ecology non-antroposentris. Konsep ini merupakan suatu istilah yang menunjuk pada setiap etika lingkungan yang tidak murni antroposentrik. Suatu konsep yang mendasari seruan pada pelestarian dan pemulihan lingkungan bukan hanya pada kepentingan pribadi manusia yang tercerahkan, melainkan juga pada nilai instrinsik dari spesiesspesies lainnya. Kedua, deep-ecology biosferik. Konsep ini merupakan sikap keprihatinan terhadap biosfer secara keseluruhan dan tidak membaut garis pemisah yang dibawahnya diandaikan tak terdapat nilai inheren yang harus dihargai. Ketiga, deep-ecology egalitarianisme biosferik, yakni suatu penegasan yang menolak hirarki nilai inheren pada semua makhluk bumi. ${ }^{35}$

Dalam konsepsi Islam, manusia merupakan khalifah di muka bumi (Q.S. al-Baqarah: 30). Secara etimologis, khalifah merupakan bentuk kata dari khulifun yang berarti pihak yang tepat menggantikan posisi pihak yang memberi kepercayaan. Adapun secara terminologis, kata khalifah mempunyai makna fungsional yang berarti mandataris, yakni pihak yang diberi tanggungjawab oleh pemberi mandat (Allah). Dengan demikian, manusia merupakan mandataris-Nya di muka bumi. Menurut Shihab, Q.S al-Baqarah: 30 tidaklah berkonotasi politis, karena diungkapkan dalam bentuk tunggal dan subyeknya berupa orang pertama tunggal. Dengan demikian, konteks ini adalah pengangkatan Adam sebagai khalifah dan dalam peristiwa tersebut memang tidak ada pihak lain yang terlibat. ${ }^{36}$ Pemahaman ini juga selaras dengan penafsiran Tahaba'taba'i yang memaknai terma khalifah pada ayat tersebut tidaklah berkonotasi politis individual, namun kosmologis komunal. Dengan demikian, Adam dalam hal ini bukanlah sebagai sosok personal, namun dimaknai sebagai simbol seluruh komunitas manusia. ${ }^{37}$ Dengan demikian, penyandang khalifah dalam hal ini adalah seluruh spesies manusia.

\footnotetext{
34 Ibid., hlm. 197-198.

35 Ibid., hlm. 199.

36 Quraish Shihab, Membumikan al-Qur'an, (Bandung: Mizan, 1993), hlm. 156-159.

37 Mujiono Abdillah, Agama Ramah..., hlm. 205.
} 
Pemahaman bahwa manusia hanya merupakan khalifah mengimplikasikan bahwa manusia bukanlah penguasa alam, namun hanya memiliki posisi sebagai mandaris-Nya di muka bumi. Hal ini tentunya tidak memposisikan manusia sebagai pusat orientasi sebagai pandanagan antroposentris radikal, namun juga memposisikan manusia sebagai pemangku mandat Allah dalam hal pemeliharaan (Q.S. al-An'am: 102, Q.S.Az-Zumar: 133). Dengan demikian, pada dasarnya, konsep etika Islam menolak paradigma shallow-ecology yang hanya menjadikan manusia sebagai pusat orientasi dan menjadikan alam sebagai ruang ekspoitatif demi kepentingan manusia. Etika Islam tidak melarang manusia untuk memanfaatkan alam, namun hal tersebut haruslah dilaksanakan secara seimbang dan tidak berlebihan. Hal ini dapat dilihat dari Q.S al-An'am: 141 yang memberi informasi kebolehan memanfaatkan tanaman, serta Q.S al-An'am: 142 yang meunjukkan kebolehan memanfaatkan binatang dan memakannya. Namun satu landasan penting yang dicatat diakhir masing-masing ayat tersebut adalah bahwa pemanfaatannya haruslah tidak berlebih-lebihan dan tidak mengikuti hawa nafsu (langkah syetan). Kedua ayat tersebut merupakan landasan adanya etika biosentrisme dan zoosentrisme dalam Islam.

\section{E. Paradigma Fiqh Lingkungan}

Fiqh lingkungan (fiqh al-biah) merupakan terobosan baru bagi upaya konservasi lingkungan hidup dengan perspektif keagamaan. Perspektif ini sekaligus menegaskan akan pentingnya pendekatan agama, termasuk produk hukumnya, dalam konservasi lingkungan sebagai tambahan bagi pendekatan disiplin ilmu lain yang telah ada. Selanjutnya kata "lingkungan", sebagi terjemahan dari kata al-biah dalam tulisan ini dilekatkan dengan kata "fiqh" yang secara istilah berarti pengetahuan tentang hukum-hukum syari' at Islam mengenai perbuatan-perbuatan manusia, yang mana pengetahuan tersebut diambil dari dali-dalil yang bersifat at-tafshiliyyah. ${ }^{38}$ Oleh karenanya, fiqh lingkungan yang dimaksud adalah pengetahuan atau tuntutan syar'i yang concern terhadap masalah-masalah ekologi atau tuntutan syar'i yang dipakai untuk melakukan kritik terhadap prilaku manusia yang cenderung

38 Abdul Wahab Khalaf, Ilmu Ushul Fiqh, (Kuwait: Dar al-Qalam, 1978), hlm.15. 
memperlakukan lingkungan secara destruktif dan eksploitatif. Fiqh lingkungan di sini juga sekaligus berarti panduan dan peraturan bagi keselamtan kosmos. Dengan kata lain, bahwa fiqh al-bi'ah merupakan upaya untuk memecahkan masalah lingkungan melalui pendekatan teks agama.

Menurut Atho', paling tidak ada empat alasan utama terkait siginifikansi munculnya pengembangan fiqh lingkungan, yakni:

Pertama, kondisi obyektif krisis lingkungan yang makin parah baik di negara-negara muslim maupun di level global. Hal ini memerlukan partisipasi dari ajaran agama Islam sebagai agama rahmatan lil 'alamin. Salah satu partisipasi ini diwujudkan dengan rumusan fiqh lingkungan. Konsep ini telah dirumuskan oleh para ulama dan intelektual muslim dan perlu dikembangkan lagi ke konsep-konsep yang lebih operasional dan melalui pelembagaan formal. Perpaduan antara nilai ajaran Islam dengan kearifan-kearifan formal sosial budaya dan hukum tentunya akan menguatkan. Dalam konteks umat Islam, hal ini akan memperkuat aspek jiwa dari sebuah hukum formal. Kedua, umat Islam memerlukan kerangka pedoman komprehensif tentang pandangan dan cara melakukan partisipasi didalam masalah konservasi lingkungan. Fiqh klasik dipandang tidak memadai lagi dan belum mengakomodir dalam bentuk operasional panduan mengenai konservasi lingkungan dalam perspektif dan wawasan krisis lingkungan modern. Ketiga, fiqh lingkungan belum dianggap sebagai disiplin yang masuk ke ranah studi Islam. Akar-akar ontologis dan epistemologisnya masih diperdebatkan sehingga dianggap sebagai bagian dari ilmu lingkungan. Memang didalam fiqh mu'amalah terdapat tema-tema mengenai lingkungan seperti thaharah, ihya al-mawat, hukum berburu, hima, dan sebagainya, namun itu masih bersifat generik dan etis. Hal ini tentunya diperlukan penjelasan yang lebih operasional, kontekstual, dan berbobot ekologis. Keempat, fiqh lingkungan sebagai 'induk' konservasi lingkungan berbasis ajara Islam perlu dimasukkan ke dalam program-program pendidikan. Hal ini sangat penting karena kesadaran mengenai konservasi lingkungan sangat efektif melalui strategi pendidikan dan kebudayaan. Dengan demikian, pengembangan fiqh lingkungan memperoleh dukungan kelembagaan Islam di samping dukungan-dukungan politik, dan atau ecothinker. ${ }^{39}$

39 Atho Mudzhar, 'Membumikan Fikih Ramah Lingkungan' dalam Mudhofir Abdullah, Al-Qur'an dan Konservasi Lingkungan', (Jakarta, Dian Rakyat, 2010), hlm. xxx-xxxvi. 
Dengan pengembangan fiqh lingkungan tentunya sangat menarik untuk dicermati. Hal ini dikarenakan rumusan tersebut diharapkan mampu mengemban dua tujuan, yakni teoritis dan praktis. Sifat teoritis disini berupa gagasan-gagasan atau konstruksi-konstruksi utama, sedangkan sifat praktis yakni menghasilkan sejumlah panduan aplikatif-operasional bagi tindakantindakan konservasi lingkungan.

Konsep fiqh lingkungan yang dirumuskan mencerminkan dinamika fiqh terkait dengan adanya perubahan konteks dan situasi. Ada dua rumusan metode yang digunakan untuk membangun fiqh lingkungan, yakni mashlahah dan maqasid asy-syariah. Mashlahah secara etimologis adalah identik dengan kata manfaat, baik dari segi lafal maupun makna. Adapun secara definisi secara sederhana, mashlahah berarti mengambil manfaat dan menolak kemadharatan dalam rangka merawat tujuan-tujuan syara'. ${ }^{40}$

Dalam ushul fiqh dikenal salah satu metodologi ijtihad, yakni mashlahah mursalah. Metode ini berinduk dari (pembagian) konsep mashlahah yang manakala ditilik dari perspektif syara' terhadap eksistensi mashlahah dan adanya keselarasan antara anggapan baik secara rasional dengan tujuan syara', mashlahah dapat dibagi menjadi tiga bagian, yaitu: mashlahah mu'tabarah, mashlahah mulghah, dan mashlahah mursalah. Pertama, mashlahah mu'tabarah, yaitu mashlahah yang berada dalam kalkulasi syara'. Dalam hal ini, dalil yang secara khusus menjadi dasar dari bentuk kemaslahatan ini, baik secara langsung ada indikator dalam syara' (munasib mu'atsir) atau pun secara tidak langsung ada indikatornya (munasib mulaim). Seperti mashlahah yang terkandung dalam pensyari'atan hukum qishash bagi pembunuhan sengaja, sebagai simbol pemeliharaan jiwa manusia. Adapun salah satu cara berhujjah dengan mashlahah ini yaitu dengan jalan analogi (qiyas), bahkan sebagian ulama menyamakan antara mashlahah mu'tabarah dengan qiyas. Seperti pengharaman segala bentuk minuman yang memabukkan dengan cara diqiyas-kan pada minuman khamr yang telah di-nash-kan keharamannya oleh al-Qur'an. Maka, muatan mashlahah dalam pengharaman segala bentuk minuman memabukkan dapat diakui eksistensinya oleh syara' karena adanya kadar mashlahah yang sama dengan pelarangan jenis minuman khamr. Kedua,

40 Mudhofir Abdullah, Masail al-Fiqhiyyah, (Yogyakarta: Teras, 2011), hlm. 94. 
mashlahah mulghah, yaitu mashlahah yang keberadaannya tidak diakui oleh syara'. Jenis mashlahah ini bisaanya berhadapan secara kontradiktif dengan bunyi nash, baik al-Qur'an maupun hadis. Seperti kandungan mashlahah yang terdapat dalam hak seorang istri menjatuhkan talak kepada suami. Mashlahah ini didasarkan pada persamaan hak antara suami-istri sebagai pelaku transaksi pernikahan. Namun, mashlahah dalam masalah ini di tolak oleh syara'. Hal tersebut diisyaratkan oleh pernyataan nash, bahwa barangkali karena pertimbangan psikologis kemanusiaan, hak menjatuhkan talak hanya dimiliki seorang suami. Ketiga, mashlahah mursalah, yaitu kemashlahatan yang eksistensinya tidak didukung syara' dan tidak pula ditolak melalui dalil yang terperinci, namun cakupan makna nash terkandung dalam substansinya. Seperti pengumpulan dan pembukuan al-Qur'an menjadi satu mushhaf, sistem pemenjaraan bagi pelaku tindak pidana sebagai wujud pengewejantahan dari ketentuan hukuman pidana dalam Islam; pengadaan mata uang berikut sirkulasinya dalam sebuah mekanisme pasar, dan lain sebagainya. Contohcontoh tersebut tidak ditemukan dalam nash ajaran agama secara tersurat, namun diakui keberadaannya oleh syara' karena memiliki implikasi yang cukup jelas untuk mengakomodir kemashlahatan umat atau kepentingan umum. Dalam mashlahah jenis inilah terdapat banyak perbedaan pendapat di kalangan para ulama dan di sini pula kecakapan ijtihad sangat dibutuhkan. ${ }^{41}$

Menjaga lingkungan hidup (hifzh al-ba'ah) bisa merupakan mashlahah mu'tabarah dan bisa juga masuk dalam bingkai mashlahah mursalah. AlQur'an hanya menyinggung tentang prinsip-prinsip konservasi dan restorasi lingkungan, seperti: larangan pengrusakan, larangan berlebih-lebihan (israf) dalam pemanfaatannya. Prinsip-prinsip ini dinamakan mashlahah mu'tabarah. Namun, sejauh mana kadar berlebih-lebihan serta teknis operasional penjagaan sama sekali tidak dapat ditemukan dalam al-Qur'an. Kita harus berijtihad sendiri bagaimana tanah pinggir sungai supaya tidak terkena erosi. Mashlahah inilah yang dinamakan mashlahah mursalah. Kebutuhan akan menjaga lingkungan tetap niscaya untuk dijalankan karena lingkungan hidup merupakan penopang segala kehidupan ciptaan Tuhan.

$\overline{41}$ Ahmad Syafi'i, "Fiqh Lingkungan: Revitalisasi Ushul al-Fiqh Untuk Konservasi dan Restorasi Kosmos", makalah dipresentasikan dalam the \#9 Annual Conference on Islamic Studies (ACIS). 
Menurut Qaradhawi sebagaimana diungkapkan oleh Abdullah, menjaga lingkungan sama dengan menjaga jiwa, menjaga akal, menjaga keturunan, dan menjaga harta. Rasionalitasnya adalah bahwa jika aspek-aspek jiwa, akal, keturunan dan harta rusak, maka eksistensi manusia didalam lingkungan menjadi ternoda. ${ }^{42}$ Pentingnya menjaga lingkungan juga dikuatkan dengan argumen Abu-Sway yang menyatakan bahwa melindungi lingkungan merupakan tujuan syari'ah tertinggi. Dengan demikian, bagi Abu-Sway, hifzh al-biah memiliki signifikasi tertinggi dan menaungi komponen maqasid alkhams. Secara gamblang, Abu-Sway menyatakan bahwa "...the destruction of the environment prevents the human being from fulfilling the concept of vicegerency on earth. Indeed, the very existence of humanity is at stake here". ${ }^{33}$ Argumen ini mempertegas prinsip maqasid asy-syariah dalam upaya global menanggulangi krisis lingkungan.

\section{F. Kesimpulan}

Krisis lingkungan hidup kontemporer yang sangat memprihatinkan tetunya harus direspon secara serius. Tidak hanya dari kalangan ilmuawan saja, krisis lingkungan juga harus direpon secara serius oleh para kalangan agamawan. Tentu saja hal ini penting, bukan hanya karena adanya kritik dari beberapa ilmuwan yang menyatakan bahwa agama merupakan akar krisis lingkungan, namun agama harus memberi peran strategis dalam hal problem lingkungan hidup kontemporer.

Dalam konteks Islam, persoalan lingkungan merupakan isu baru yang penting untuk dikaji. Konstruksi paradigma Islam selama ini dianggap belum secara memuat persoalan lingkungan hidup. Dalam hal teologi, paradigma berpikir yang muncul masih lebih bercorak klasik. Kuatnya paradigma teosentris dalam hal konsep, dan kenyataan antroposentrisme dalam tindakan menimbulkan problem tersendiri. Corak ini kemudian menimbulkan implikasi etika yang berujung pada menempatkan manusia sebagai pusat orientasi. Bahkan dalam ranah fiqh yang merupakan landasan perilaku dan perbuatan manusia, persoalan lingkungan tidak mendapatkan porsi. Selama

42 Mudhofir Abdulloh, Al-Qur'an dan ..., hlm. 277.

43 Ibid., hlm. 279. 
ini, fiqh hanya bergulat dalam dimensi nalar klasik saja yang melahirkan qira'ah mutakarrirah. Padahal khazanah klasik, tidak mempunyai kerangka secara spesifik dalam konsep interaksi manusia dengan lingkungan. Dari kenyataan inilah, penting kira mencari konstruksi paradigma Islam yang dapat menjadi landasan dalam berinteraksi dengan lingkungan.

\section{DAFTAR PUSTAKA}

Abdillah, Mujiono, Agama Ramah Lingkungan Perspektif Al-Qur'an, Jakarta: Paramadina, 2001. , "Rekonstruksi Teologi Lingkungan dalam Pembangunan Masyarakat Madani”, dalam Innovatio, vol. 5, No. 10 Edisi JuliDesember 2006.

Abdullah, Mudhofir, Al-Qur'an dan Konservasi Lingkungan', Jakarta, Dian Rakyat, 2010. , Masail al-Fiqhiyyah, Yogyakarta: Teras, 2011.

Bakar, Taqiyuddin Abu, Kifayah al-Akhyar, Semarang: Toha Putra, tt.

Barbour, Ian G., Issue In Science and Religion, New York: Harper Torcbooks, 1966.

, When Science Meet Religion: Enemies, Stranger, or Partners?, New York: Harper Collins Publisher, 2000.

Fukuyama, Francis, The Great Disruption: Human Nature and the Reconstruction of Social Order, New York: The Free Press, 1999.

Hanafi, Hasan, Dari Akidah ke Revolusi: Sikap Kita Terhadap Tradisi Lama, terj. Asep Usman dkk, Jakarta: Paramadina, 2003.

Harun, Martin "Taklukkan Bumi dan Berkuasalah..." dalam Mujiono Abdillah, Agama Ramah Lingkungan Perspektif Al-Qur'an, Jakarta: Paramadina, 2001.

Kensky, Tikva Frimer-, "Ecology in a Biblical Perspective" dalam Richard C. Foltz, Worldviews, Religion, and the Environment: A Global Anthology, Australia: Thomson Wadsworth, 2003.

Keraf, A. Sonny, Etika Lingkungan Hidup, Jakarta: Kompas, 2010. 
Khalaf, Abdul Wahab, 'Ilmu Ushul Figh, Kuwait: Dar al-Qalam, 1978.

Khalid, Fazlun M., "The Disconnected People" dalam Richard C. Foltz, Worldviews, Religion, and the Environment: A Global Anthology, Australia: Thomson Wadsworth, 2003.

Mudzhar, Atho, 'Membumikan Fikih Ramah Lingkungan' dalam Mudhofir Abdullah, Al-Qur'an dan Konservasi Lingkungan', Jakarta, Dian Rakyat, 2010 .

Richard C. Foltz (ed.), Wordview, Religion, and the Environment: A Global Anthology, Thomson Wadsworth, 2003.

Shihab, Quraish Membumikan al-Qur'an, Bandung: Mizan, 1993.

Stowasser, Barbara Freyer, Women in the Qur'an, Tradition, and Intepretation, New York: Oxford University press, 1994.

Syafi'i, Ahmad, "Fiqh Lingkungan: Revitalisasi Ushul al-Fiqh Untuk Konservasi dan Restorasi Kosmos", makalah dipresentasikan dalam the \#9 Annual Conference on Islamic Studies (ACIS).

Thalhah dan Ahmad Mufid, Figh Lingkungan: Menjaga Bumi Memahami Makna Kitab Suci, Yogyakarta: Total Media, 2008.

White, Jr. L. 'The Historical Roots of Our Ecologic Crisis”, Science vol. 155, 1967.

Zakariyya, Abi Yahya, Fath al-Wahhab, Semarang: Toha Putra, tt. 